\title{
Seismic Performance of Partially Dismantled Buildings
}

\author{
Jagat Kumar Shrestha \\ Department of Civil Engineering, Pulchowk Campus, Institute of Engineering, Tribhuvan University, Nepal. \\ Corresponding author: jagatshrestha@ioe.edu.np
}

Received: May 18, 2017

Revised: Dec 21, 2017

Accepted: Dec 25, 2017

\begin{abstract}
This study carries out the comparative study of Seismic Performance of residential buildings after partial dismantling for road widening works in Kathmandu city. Two types of buildings were taken for the study, i.e. 4 storey building and 6 storey building. The Buildings were assessed for bare frames. The detail level of the seismic evaluation was carried out by preparing 3-D modeling of the buildings in SAP2000 software by nonlinear static pushover analysis. The capacity of the buildings has been found significantly decreased after the partial dismantling of the building due to the road widening works. The behavior of buildings has been found like a strong beam and weak column mechanism.
\end{abstract}

Keywords: Partially dismantled buildings, seismic performance, capacity curve

\section{Introduction}

Kathmandu Road Widening Project is one of the most significant infrastructure improvement projects in the Kathmandu Metropolitan City jointly run by Kathmandu Metropolitan City, the Department of Roads, the Kathmandu Valley Development Authority, the Metropolitan Traffic Police Range, the Department of Urban Development and Physical Planning and Works and the Nepal Police. However, in the widening of roads in city areas, the partial dismantling of buildings cannot be avoided. This activity may make these partially cut buildings vulnerable to earthquakes as the Kathmandu valley. This study carries out the comparative study of seismic vulnerability assessment of the residential buildings before and after the partial dismantling.

Partial demolishing a building on either side of the roads, cutting its vital components like columns, beam etc. may create more vulnerable situations to earthquake associated risks as the Kathmandu valley lies in a highly risky zone for earthquakes. So, it is the necessity to assess the vulnerability of the buildings due to road widening in order to have information about how much the vulnerability has been increased after the demolishment of the buildings partly. Furthermore, it will provide a proper basis and methods for the retrofitting and re-strengthening of the buildings to minimize the damage by the upcoming earthquakes. Fig. 1 shows the photographs of some partially dismantled residential buildings during Kathmandu Road Widening Project works. 

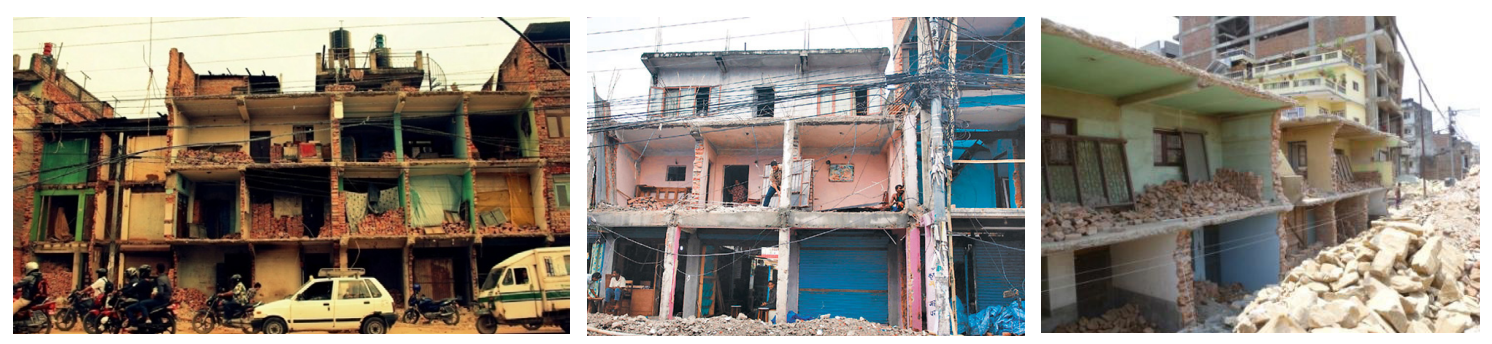

Fig. 1: Dismantled buildings during Road Widening Project in Kathmandu.

\section{Structural Models and Analysis}

Reinforced concrete structures have been partly dismantled during the road widening works has been considered for the studies to evaluate the seismic performance of the buildings. The buildings were modeled as three-dimensional models of the structure for before and after dismantles were developed on CSI SAP2000 Software. The building structure was modeled and analyzed for bare frame model.

\subsection{Model Development}

Two hypothetical buildings of 4 and 6 storey RCC framed residential buildings have been considered for the detailed investigation. The descriptions of the buildings are as follows:

\section{Building type 1}

Building Dimension

No of Stories

Storey Height

Floor/Roof

Parapet Wall Height

Earthquake Zone

Lateral Load Resisting System

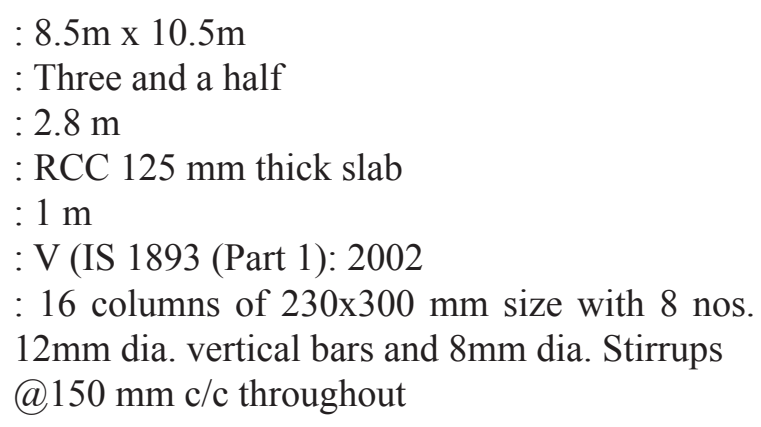

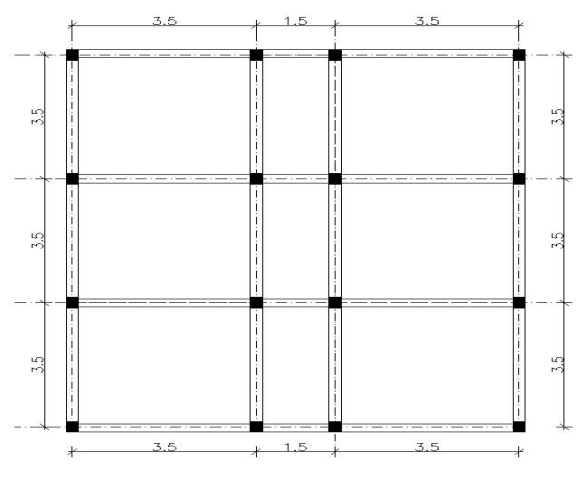

BUILDING BEFORE DISMANTLE

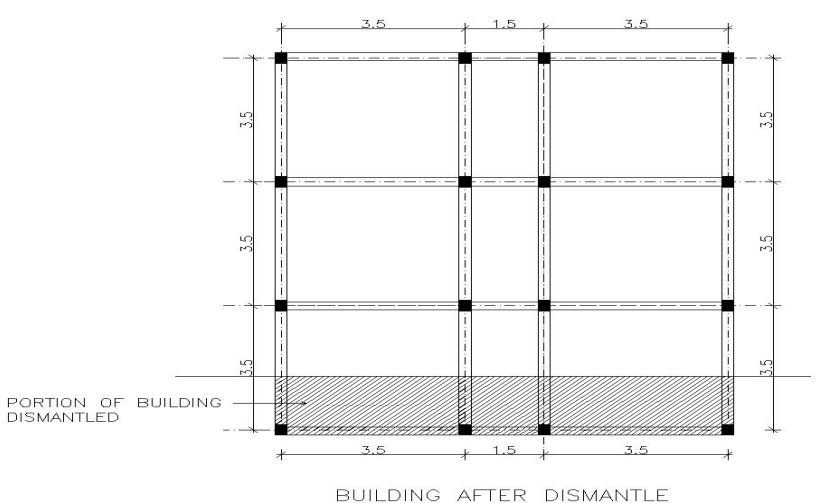

BUILDING AFTER DISMANTLE

Fig. 2: Building type 1 before and after dismantling. 


\section{Building type 2}

Building Dimension
No of Stories
Storey Height
Floor/Roof
Parapet Wall Height
Earthquake Zone
Lateral Load Resisting System
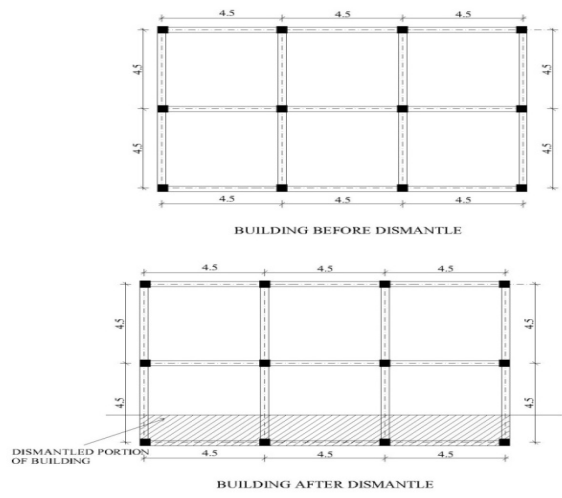

$: 13.5 \mathrm{~m} \times 9 \mathrm{~m}$

: Five and a half

: $3 \mathrm{~m}$

: RCC $125 \mathrm{~mm}$ thick slab

$: 1 \mathrm{~m}$

: V (IS 1893 (Part 1): 2002

: 12 columns of $300 \times 300 \mathrm{~mm}$ size with 8 nos. $16 \mathrm{~mm}$ dia vertical bars and $8 \mathrm{~mm}$ dia. Stirrups (a) $150 \mathrm{~mm} \mathrm{c} / \mathrm{c}$ through out

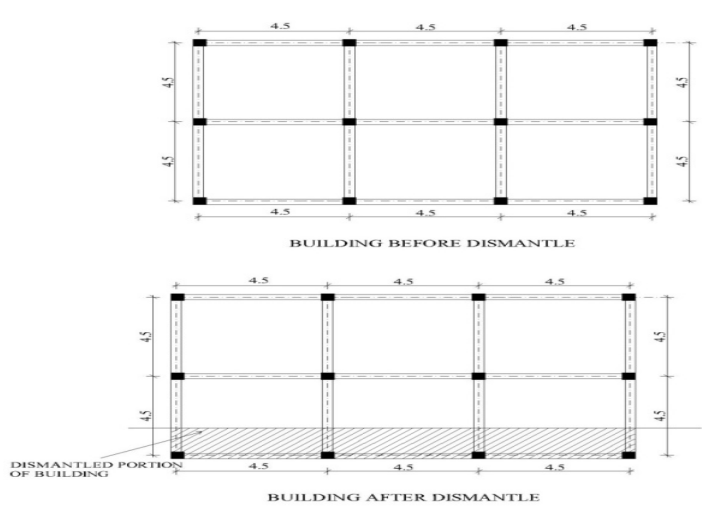

Fig. 3: Building type 2 before and after dismantling.

\section{Material properties}

The following material properties have been considered for the modeling of buildings adopted from IS 456: 2000 for RCC components as follows:

Reinforcing Bar: Yield strength of reinforcing bar, $\mathrm{f}_{\mathrm{y}}=500 \mathrm{MPa}(\mathrm{Fe} 500)$

Concrete:

Unit weight $=23.5616 \mathrm{kN} / \mathrm{m}^{3}$

Characteristic compressive strength, $\mathrm{f}_{\mathrm{ck}}=\mathrm{M} 15$ (For Building type 1)

Characteristic compressive strength, $\mathrm{f}_{\mathrm{ck}}=\mathrm{M} 20$ (For Building type 2)

Tensile strength (flexural strength), $\mathrm{f}_{\mathrm{cr}}=3.83 \mathrm{~N} / \mathrm{mm}^{2}$

Shear strength, $\tau_{\mathrm{c}}=3.5 \mathrm{~N} / \mathrm{mm}^{2}$

Young's modulus of elasticity, $\mathrm{E}_{\mathrm{c}}=5000 \sqrt{\mathrm{f}_{\mathrm{ck}}}=19364.92 \mathrm{~N} / \mathrm{mm}^{2}$ (For Building type 1)

Young's modulus of elasticity, $E_{c}=5000 \sqrt{ } \mathrm{f}_{\mathrm{ck}}=22360.30 \mathrm{~N} / \mathrm{mm}^{2}$ (For Building type 2)

Poisson's ratio, $v_{c}=0.2$

\section{Structural model}

The buildings were modeled for bare frames. For pushover analysis, a point-plasticity approach is considered for modeling nonlinearity, wherein the plastic hinge is assumed to be concentrated at a specific point in the frame member under consideration. Beam and column elements in this study were modeled with flexure (M3 for beams and P-M2-M3 for columns) hinges at possible plastic regions under lateral load (i.e., both ends of the beams and columns). 


\subsection{Analysis}

A Pushover analysis is carried out which is a nonlinear static procedure [2] wherein monotonically increasing lateral loads are applied to the structure till a target displacement is achieved or the structure is unable to resist further loads.

Seismic evaluation of existing RC framed building is generally performed by pushover analysis to verify the adequacy of the structural system. One of the non-linear static processes is the capacity spectrum method that uses the interaction of the capacity curve and a reduced response spectrum to estimate maximum displacement. This method provides a graphical representation of the global force-displacement capacity curve of the structure (i.e. pushover curve) and compares it to the response spectra representations of the earthquake demand. It is commonly used a tool in the evaluation and retrofit design identifying modes of failure and the potential for the progressive collapse of frames. In order to provide reliable limiting earthquake-induced lateral displacements to levels at which damage sustained by building element will be within acceptable levels for intended performance objective as shown in Fig. 4.

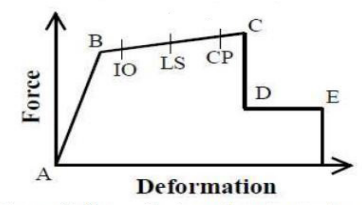

Fig. 4: Typical Capacity Curve.

The ATC-40 [1]) and FEMA-273 [4] documents have developed modeling procedures, acceptance criteria and analysis procedures for a pushover analysis. These documents define force-deformation criteria for hinges used in pushover analysis. As shown in Fig. 4, five points labeled A, B, C, D, and $\mathrm{E}$ are used to define the force-deflection behavior of the hinge and three points labeled IO, LS, and $\mathrm{CP}$ is used to define the acceptance criteria for the hinge. The values assigned to each of these points vary depending on the type of member as well as many other parameters defined in ATC-40 [1].

Pushover analysis of the buildings: In the present study, SAP2000 V15.2 was used for displacementcontrolled pushover analysis of building frames. Hinge properties for the RC members of the building are determined using the SAP2000 auto hinge assign according to FEMA 356 [3] hinges. Then, the output of pushover analysis is plotted as a relationship between lateral shear at the base of structures and corresponding displacement at any point on the structure (displacement at the roof is monitored) for several lateral displacement increments until target displacement is reached or structure becomes unstable because of failure of critical elements.

Material modeling for pushover analysis: In addition to the elastic material properties required in linear analysis, non-linear material properties are required in pushover analysis. In SAP2000, non-linearity in members is not distributed along their whole length; instead, lumped plasticity is modeled at desired locations on structural members.

Location of plastic hinges in RC members was assumed to form at a distance equal to half the average plastic hinge length $\left(l_{\mathrm{p}}\right)$ from their ends. It is calculated by the following expression [5]:

$$
1_{\mathrm{p}}=0.08 \mathrm{~L}+0.022 \mathrm{~d}_{\mathrm{b}} \mathrm{f}_{\mathrm{y}}
$$


Where, $\mathrm{L}$ is the length of the member in $\mathrm{m}, \mathrm{d}_{\mathrm{b}}$ diameter of longitudinal reinforcement in $\mathrm{m}$, and $\mathrm{f}_{\mathrm{y}}$ is yield stress of longitudinal reinforcement in MPa. All the beam-column joints in the frames assumed to be rigid. In columns, plastic hinges that generally develop are those corresponding to axial force- bending moment (P-M hinges), bending moment - bending rotation (M- $\Theta$ hinges), and shear force- shear deformation (V- $\Delta$ hinges).

Plastic hinge properties of RC members: Non-linear material properties of all the structural members are specified for plastic hinges in pushover analysis. The P-M hinges for RC columns and $\mathrm{M}-\mathrm{\Theta}$ hinges for RC beam were specified using the auto hinge assign from SAP2000 using the properties from FEMA 356 (2000), Table 6-8 and Table 6-7[3] respectively.

Target displacement: The target displacement serves as an estimate of the global displacement of the structure is expected to experience in a designed earthquake at the center of mass of the structure.

The target displacement is calculated by [3], $\mathrm{dt}=\mathrm{C} 0 \mathrm{C} 1 \mathrm{C} 2 \mathrm{C} 3 \mathrm{SaTe}^{2} \mathrm{~g} / 4 \Pi^{2}$

where: $\mathrm{C} 0=$ Modification factor for SDOF \& MDOF

$\mathrm{C} 1=$ Modification Factor to relate expected maximum inelastic displacements to displacements calculated for linear elastic response

$\mathrm{C} 2$ = Modification factor to represent the effect of hysteresis shape on the maximum displacement response

C3 = Modification Factor to represent increased displacements due to dynamic P- Delta effects.

$\mathrm{Sa}=$ Response spectrum acceleration

$\mathrm{Te}=$ Characteristic period of the response spectrum.

\section{Results}

The building frames before and after dismantle were studied analytically by pushover analysis. Based on the numerical analysis, results obtained are presented as follows:

Pushover/Capacity Curves are obtained from the above analysis for the different cases. Fig. 5 shows the comparison of the capacity of the buildings before dismantling and the building after dismantling of $25 \%, 50 \%, 75 \%, 100 \%$ of the front span. It was noticed that the capacity of the building has been greatly decreased after dismantling.
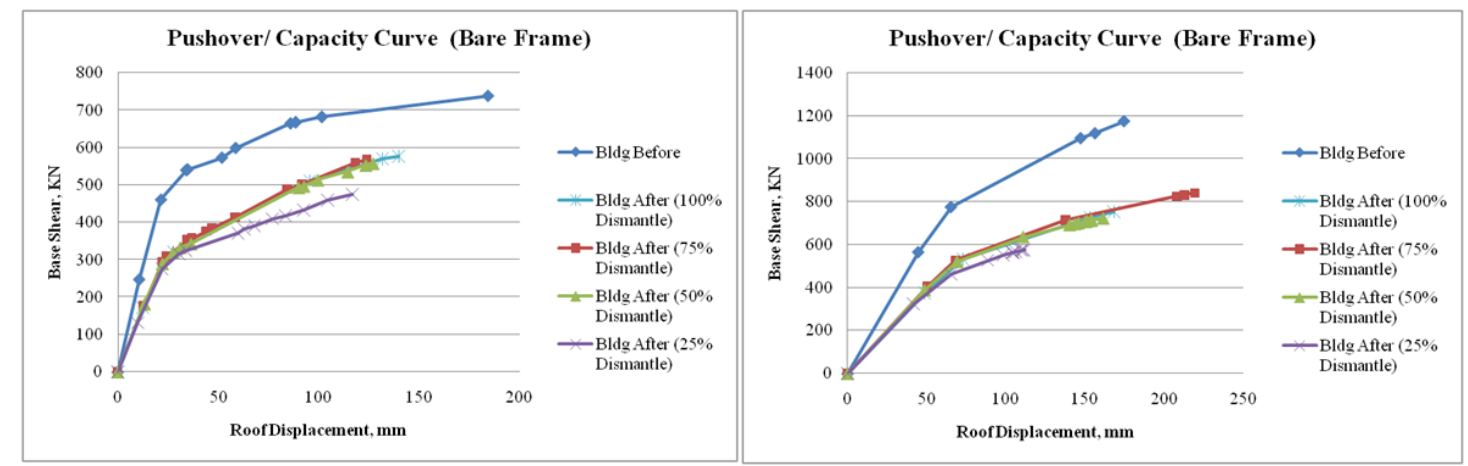

Fig. 5: Pushover/Capacity curve (Building 1 and Building 2). 
ATC-40 Capacity Spectrum has been obtained using the interaction of the base shear and the displacements calculated from the results of the pushover analysis, the capacity curve and capacity spectrum of the structures are calculated for $75 \%$ dismantling (Fig. 6) for building 1. Similarly, the spectrum of the structure is calculated $50 \%$ and $25 \%$ dismantling for the same building (Fig. 7). The demand spectrum (Fig. 8) is also generated for a design seismic load using the design response spectrum for the building.

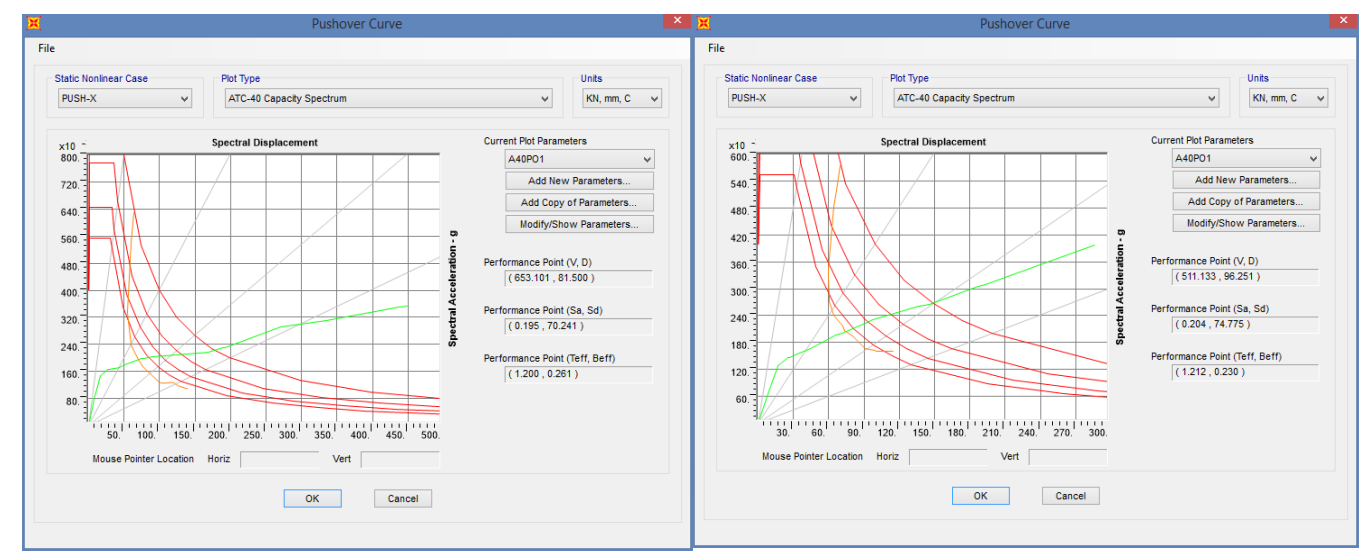

Fig. 6: ATC-40 Capacity Curve for Building before and after 75\% dismantling.

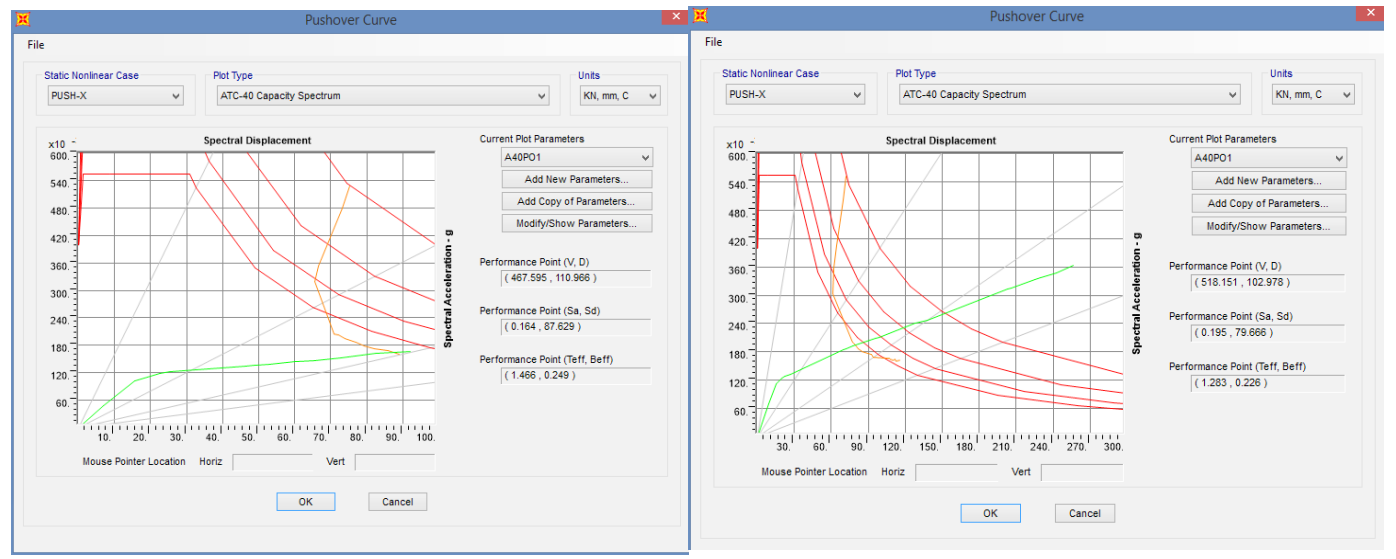

Fig. 7: ATC-40 Capacity Curve for building after 50\% and 25\% dismantling. 


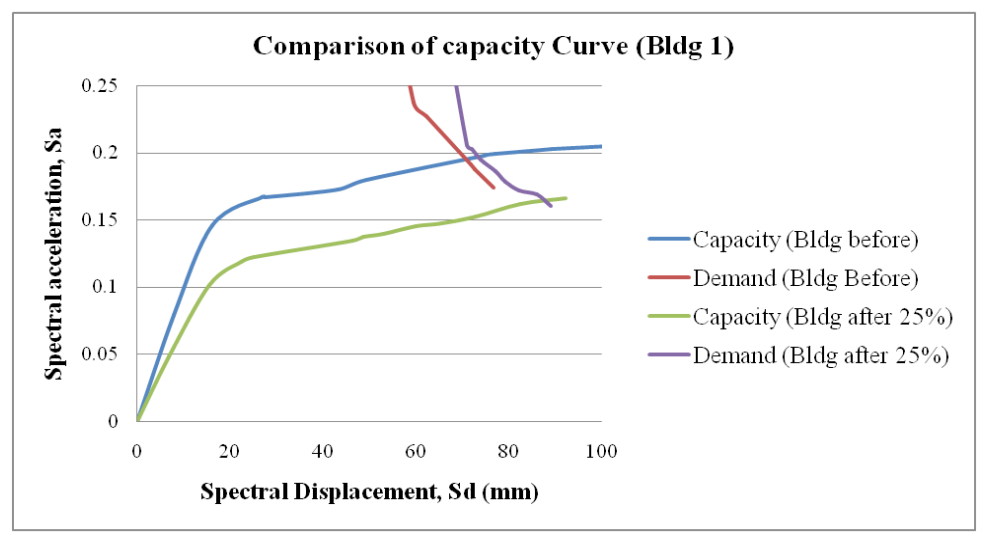

Fig. 8: Comparison of ATC 40 capacity curve before and after $25 \%$ dismantle

A Performance Point, which represents the state of a maximum inelastic capacity of the structure, is found through the cross point of the Capacity Spectrum and Demand Spectrum for a given damping ratio. In FEMA Load (Base Shear) - Displacement of the pushover analysis is transformed into the Spectral Acceleration (Sa) vs. Spectral Displacement (Sd) curve. Characteristics of performance point and target displacement are shown in Table 1 and Table 2.

Table 1: Characteristics of Performance Point (Building 1).

\begin{tabular}{|c|c|c|c|c|c|}
\hline \multirow{2}{*}{ S.N. } & \multirow{2}{*}{ Description } & \multirow{2}{*}{ Bldg Before } & \multicolumn{3}{|c|}{ Building After } \\
\cline { 4 - 6 } & & & $75 \%$ Dismantle & $50 \%$ Dismantle & 25\% Dismantle \\
\hline 1 & Roof Displacement & 81.5 & 96.251 & 102.978 & 110.996 \\
2 & Base Shear & 653.101 & 511.13 & 518.15 & 467.59 \\
3 & Spectral Acceleration & 0.195 & 0.204 & 0.195 & 0.164 \\
4 & Spectral Displacement & 70.24 & 74.755 & 79.666 & 87.629 \\
5 & Eff. Time Period & 1.2 & 1.212 & 1.283 & 1.466 \\
6 & Eff. Damping & 0.261 & 0.23 & 0.226 & 0.249 \\
\hline
\end{tabular}

Table 2: Target Displacement according to FEMA 356 coefficient (Building 1).

\begin{tabular}{|c|c|c|c|c|c|c|}
\hline \multirow{2}{*}{ S.N. } & \multirow{2}{*}{ Description } & \multirow{2}{*}{ Bldg Before } & \multicolumn{4}{|c|}{ Building After } \\
\cline { 4 - 7 } & & & $100 \%$ Dismantle & $75 \%$ Dismantle & $50 \%$ Dismantle & $25 \%$ Dismantle \\
\hline 1 & Base Shear, KN & 3226.604 & 2385.75 & 2428.82 & 2321.168 & 2302.623 \\
2 & Target Displacement, $\mathrm{mm}$ & 35.808 & 35.415 & 38.468 & 46.791 & 50.187 \\
\hline
\end{tabular}

Roof Drift and Inelastic Roof Drift is found as shown in Table 3 and Table 4.

Table 3: Roof Displacement and inelastic Roof Displacement (Building 1).

\begin{tabular}{|c|c|c|c|c|c|c|c|c|}
\hline S.N. & Roof Drift & Building & \multicolumn{3}{|c|}{ Building After } & \multicolumn{3}{|c|}{ Performance Level } \\
\cline { 4 - 9 } & & $\begin{array}{c}75 \% \\
\text { dismantle }\end{array}$ & $\begin{array}{c}50 \% \\
\text { dismantle }\end{array}$ & $\begin{array}{c}25 \% \\
\text { dismantle }\end{array}$ & $\begin{array}{c}\text { Intermediate } \\
\text { Occupancy }\end{array}$ & $\begin{array}{c}\text { Damage } \\
\text { control }\end{array}$ & $\begin{array}{c}\text { Life } \\
\text { Safety }\end{array}$ \\
\hline 1 & $\begin{array}{c}\text { Maximum Total } \\
\text { Drift }\end{array}$ & 0.0131 & 0.0150 & 0.0157 & 0.0168 & 0.01 & $0.01-0.02$ & 0.02 \\
& $\begin{array}{c}\text { Maximum } \\
\text { Inelastic Drift }\end{array}$ & 0.0108 & 0.0126 & 0.0133 & 0.0147 & 0.005 & $\begin{array}{c}0.005- \\
0.015\end{array}$ & no limit \\
\hline
\end{tabular}


Table 4: Roof Displacement and inelastic Roof Displacement (Building 2).

\begin{tabular}{|c|c|c|c|c|c|c|c|c|}
\hline \multirow[b]{2}{*}{ S.N. } & \multirow[b]{2}{*}{ Roof Drift } & \multirow[b]{2}{*}{$\begin{array}{l}\text { Building } \\
\text { Before }\end{array}$} & \multicolumn{3}{|c|}{ Building After } & \multicolumn{3}{|c|}{ Performance Level } \\
\hline & & & $\begin{array}{c}75 \% \\
\text { dismantle }\end{array}$ & $\begin{array}{c}50 \% \\
\text { dismantle }\end{array}$ & $\begin{array}{c}25 \% \\
\text { dismantle }\end{array}$ & $\begin{array}{l}\text { Intermediate } \\
\text { Occupancy }\end{array}$ & $\begin{array}{c}\text { Damage } \\
\text { control }\end{array}$ & $\begin{array}{c}\text { Life } \\
\text { Safety }\end{array}$ \\
\hline 1 & $\begin{array}{c}\text { Maximum Total } \\
\text { Drift }\end{array}$ & 0.0129 & 0.0151 & 0.0155 & 0.0165 & 0.01 & $0.01-0.02$ & 0.02 \\
\hline 2 & $\begin{array}{l}\text { Maximum } \\
\text { Inelastic Drift }\end{array}$ & 0.0094 & 0.0115 & 0.0145 & 0.0157 & 0.005 & $\begin{array}{c}0.005- \\
0.015\end{array}$ & no limit \\
\hline
\end{tabular}

Plastic hinge patterns at the different step for Building type 1 is observed as shown in Fig. 9 and Fig. 10.
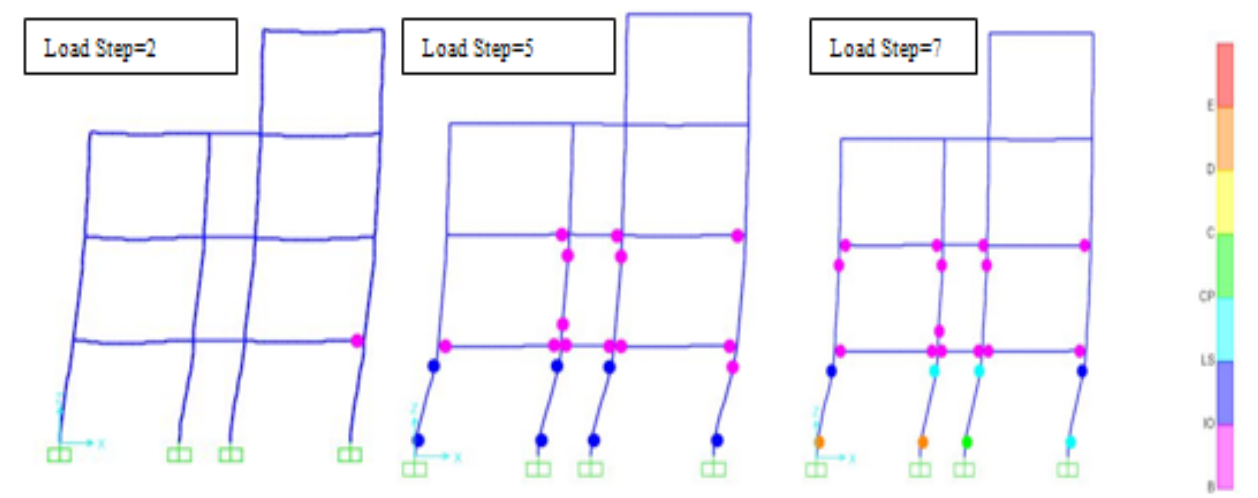

Fig. 9: Plastic hinge patterns at different load steps on Building before dismantling (Building 1).
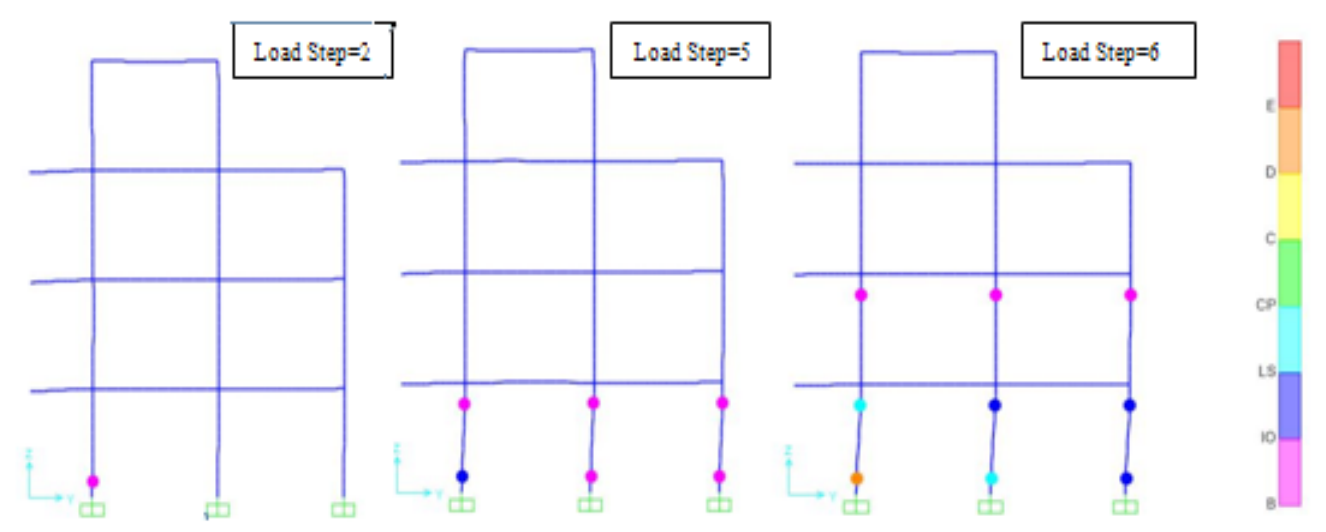

Fig. 10: Plastic hinge patterns at different load steps on 50\% dismantling (Building 1).

Fig. 9 shows the plastic hinge patterns at the three steps of loading, i.e. 2, 5 and 7 . The first hinge formed is on beam but at the later stage hinges formed on columns.

Similarly, Fig. 10 shows the plastic hinge patterns at three steps of loading i.e. 2, 5 and 6 steps. All plastic hinges formed in the columns. This shows that the building behaves like the strong beam 
and weak column mechanism. Furthermore, in the sequence of plastic hinges formation the plastic hinges formed in the columns adjacent to the dismantled portion.

\section{Conclusion}

Two types of residential buildings were assessed and analyzed for the cases before and after dismantling of $100 \%, 75 \%, 50 \%$ and $25 \%$ of the front span due to the road widening. The overall performance of the buildings before and after dismantling was investigated. The major conclusions drawn from the study are as follows:

1. The capacity of the building decreases after dismantling of a portion of the front span. The capacity of the building decreases as the percentage of the dismantling of the front span decreases.

2. The buildings behave like the strong beam and weak column mechanism, as the sequence of formation of plastic hinges in the frame members is found in the columns only. The initial hinges are formed in the column adjacent to the dismantled portion of the buildings which clearly indicates the level of vulnerability.

3. Both roof drift and inelastic roof drift values were observed to be increased after dismantling of the building and was found to be higher in $25 \%$ dismantling case.

\section{References}

[1] ATC-40 (1996), Seismic Evaluation and Retrofit of Concrete Building. Applied Technology Council, California.

[2] Goel RK (2008), Evaluation of Current Nonlinear Static Procedures for Reinforced Concrete Buildings. The 14th World Conference on Earthquake Engineering, October 12-17, 2017, Beijing, China.

[3] FEMA 356 (2000), Pre-standard and Commentary for the Seismic Rehabilitation of the Buildings. Federal Emergency Management Agency \& American Society of Civil Engineers.

[4] FEMA 273 (1997), NEHRP Handbook for the Seismic Rehabilitation of Buildings. Building Seismic Safety Council, Washington, D.C.

[5] Pauley T and Priestley MJN (1991), Seismic Design of Reinforced Concrete and Masonry Buildings. John Wiley \& Sons, Inc. 